\title{
Chemical Composition of Rhodocyclus gelatinosus Biomass Produced in Poultry Slaughterhouse Wastewater
}

\author{
Elisa Helena Giglio Ponsano ${ }^{1 *}$, Pedro Magalhães Lacava ${ }^{2}$ and Marcos Franke Pinto ${ }^{1}$ \\ ${ }^{1}$ Departamento de Apoio; Produção e Saúde Animal; Curso de Medicina Veterinária; Universidade Estadual \\ Paulista; Caixa Postal 341; CEP 16050-680; Araçatuba - SP - Brazil. ${ }^{2}$ Departamento de Bioquímica; Instituto de \\ Química; Universidade Estadual Paulista; Caixa Postal 355; CEP 14801-970; Araraquara - SP - Brazil
}

\begin{abstract}
Rhodocyclus gelatinosus $R_{1}$ grew photoautotrophically in poultry slaughterhouse wastewater inside glass columns (90x670 mm) during 7 days at $31 \pm 4^{\circ} \mathrm{C}$, under anaerobiosis and lightness supplied by daylight plus 3 (100W) incandescent and $4(40 \mathrm{~W})$ fluorescent lamps. The culture was centrifuged (4,500xg/20 min) and lyophilized to originate a bacterial biomass with $7.1 \%$ moisture content. Chemical composition investigation showed $67.6 \%$ crude protein, $27.6 \%$ total carbohydrate, $0.6 \%$ lipids and $4.2 \%$ ash (dry weight). Amino acid composition of the biomass was similar to others described in the literature for Rhodocyclus gelatinosus and for other photosynthetic bacteria. Effluent COD removal after cultivation and elimination of the biomass was around $90 \%$. The valuable chemical composition of Rhodocyclus gelatinosus $R_{l}$ biomass and the high content in essential amino acids signs for the potential use of the product in poultry feed.
\end{abstract}

Key words: Rhodocyclus gelatinosus, biomass, poultry slaughterhouse wastewater, chemical composition, amino acid composition, COD removal

\section{INTRODUCTION}

Biomass production for use as protein source in human foods or animal feeds comprises the production of dried cells of different microorganisms (algae, actinomycetes, bacteria, yeasts, molds and higher funghi) grown in largescale culture systems. This activity represents a promising application of biotechnology, which is even more successful when associated to the utilization of sewage or industrial wastes as substrate (Litchfield, 1983). Anoxygenic phototrophic bacteria, especially Purple NonSulfur Bacteria (PNBS) are widely distributed in nature (soil, water and wastes) and have special importance because of their potential role in the degradation of industrial pollutants (Sasikala et al., 1995). Photosynthetic bacteria grown in such substrates are known to produce biomass rich in protein with good contents of essential amino acids, besides carbohydrates, lipids, minerals, vitamins and carotenoids, what suggests the potential use of the product in animal feed (Prasertsan et al., 1993 $3^{\mathrm{a}, \mathrm{b}}$ ). Rhodocyclus gelatinosus, a PNSB, is of common occurrence in many industrial effluents where it grows well photoautotrophically because of the ability to hydrolyze starch and gelatin due to peculiar hydrolyzing enzymes it produces. It also produces carotenoid pigments of the spirilloxanthin

\footnotetext{
* Author for correspondence
} 
alternative series, which confers red color to its cultures (Trüper and Imhoff, 1992; Brock et al., 1994; Holt et al., 1994) and may find application in animal feed due to the possibility of intensifying animal tissue color (Kobayashi and Kurata, 1978; Noparatnaraporn and Nagai, 1986). This work investigated the chemical composition of Rhodocyclus gelatinosus biomass produced in poultry slaughterhouse wastewater aiming at a further use in the supplementation of broiler and laying hens rations.

\section{MATERIALS AND METHODS}

Substrate: Poultry slaughterhouse wastewater was filtered thrice (once through a metal sieve and twice through paper filter Whatman ${ }^{\mathrm{TM}}$ \# 3), steam heated for 40 minutes and cooled to $25^{\circ} \mathrm{C}$. This operation was repeated for three consecutive days.

Microbial culture: $R$. gelatinosus $\mathrm{R}_{1}$ was isolated from poultry slaughterhouse wastewater as described previously (Ponsano, 2000).

Culture medium: Pfennig's medium (Pfennig, 1974) containing (g/l) $\mathrm{KH}_{2} \mathrm{PO}_{4} 0.5 ; \mathrm{MgSO}_{4} .7 \mathrm{H}_{2} \mathrm{O}$ $0.4 ; \mathrm{NaCl} 0.4 ; \mathrm{NH}_{4} \mathrm{Cl} 0.4 ; \mathrm{CaCl}_{2} .2 \mathrm{H}_{2} \mathrm{O} 0.05$; organic compound 1 ; yeast extract 0.2 ; ferric citrate 0.005 ; trace elements solution $10 \mathrm{ml}$ $\left(\mathrm{FeSO}_{4} .7 \mathrm{H}_{2} \mathrm{O} \quad 200 \mathrm{mg} ; \mathrm{ZnSO}_{4} \cdot 7 \mathrm{H}_{2} \mathrm{O} \quad 10 \mathrm{mg}\right.$; $\mathrm{MnCl}_{2} .4 \mathrm{H}_{2} \mathrm{O} 3 \mathrm{mg} ; \mathrm{H}_{3} \mathrm{BO}_{3} 30 \mathrm{mg} ; \mathrm{CoCl}_{2} \cdot 6 \mathrm{H}_{2} \mathrm{O} 20$ $\mathrm{mg} ; \mathrm{CuCl}_{2} \cdot 2 \mathrm{H}_{2} \mathrm{O} 1 \mathrm{mg} ; \mathrm{NiCl}_{2} \cdot 6 \mathrm{H}_{2} \mathrm{O} 2 \mathrm{mg}$; $\mathrm{Na}_{2} \mathrm{MoO}_{4} \cdot 2 \mathrm{H}_{2} \mathrm{O} 3 \mathrm{mg}$ ) was used (pH 7.0). It was autoclaved at $121^{\circ} \mathrm{C}$ for 15 minutes.

Vitamin solutions: Biotin $0.0015 \%$ sol.: biotin $1.5 \mathrm{mg}$; distilled water $100 \mathrm{ml}$. Membrane filtration on Millipore ${ }^{\mathrm{TM}} 0.22 \mu \mathrm{m}$. Thiamine $0.005 \%$ sol.: thiamine- $\mathrm{HCl} 5 \mathrm{mg}$; distilled water $100 \mathrm{ml}$. Membrane filtration on Millipore ${ }^{\mathrm{TM}} 0.22$ $\mu \mathrm{m}$.

Inoculum production: Loops of $R$. gelatinosus $\mathrm{R}_{1}$ maintained in semi-solid agar (Pfennig's medium plus $1.2 \%$ bacteriological agar) was transferred to screw-cap test tubes $(15 \times 180 \mathrm{~mm})$, which were completely filled with Pfennig's medium enriched with $1 \mathrm{ml} / \mathrm{l}$ of each vitamin solution (both added after autoclaving). Tubes were tightly closed to keep anaerobiosis atmosphere and incubated for 7 days in an oven at $32 \pm 2^{\circ} \mathrm{C}$ and $1400 \pm 200$ lux, generated by incandescent (40W) and fluorescent (15W) lamps. The contents of these tubes were transferred to $500 \mathrm{ml}$ glass cylinders $(10 \% \mathrm{v} / \mathrm{v})$, which were filled with Pfennig vitamin-enriched medium and closed with glass stoppers. Incubation conditions were the same as described above, until the cultures reach absorbance of 0.3 at $600 \mathrm{~nm}$ (7 to 10 days), read in a Femto model 432 spectrophotometer, using Pfennig's medium as the blank.

Biomass production: Contents of the glass cylinders were slowly transferred $(10 \% \mathrm{v} / \mathrm{v})$ to glass columns $(90 \times 670 \mathrm{~mm})$, which were filled with substrate and covered with rubber stoppers for anaerobiosis environment. Incubation was carried at $31 \pm 4^{\circ} \mathrm{C}$ and lightness was supplied by the daylight plus $3(100 \mathrm{~W})$ incandescent and 4 (40W) fluorescent lamps. After 7 days, these cultures were centrifuged at $4,500 \times \mathrm{g}$ for 20 minutes (Beckman model $\mathrm{J} 6 \mathrm{M}$ ) at $0^{\circ} \mathrm{C}$ and the slime was lyophilized (MLW model LGA 05), resulting in $R$. gelatinosus $\mathrm{R}_{1}$ biomass.

\section{$R$. gelatinosus $\mathbf{R}_{1}$ biomass composition:} Moisture, crude protein, lipid and ash contents of the biomass were determined according to Brasil (1998). Total carbohydrate was found by difference. Amino acid composition was determined by HPLC after cell hydrolysis with $\mathrm{HCl} 6 \mathrm{~N}$ at $105^{\circ} \mathrm{C}$ for 22 hours with post-column reactor, ninhydrin as color reagent and UV detector at $520 \mathrm{~nm}$ for the readings. Analyzes were performed in triplicates.

Process productivity: Productivity was calculated from total volume of substrate utilized and total grams of biomass produced in the process, considering 7 days of cultivation (Aiba et al., 1971).

Chemical Oxygen Demand: Chromosulfuric acid oxidation method (COD cell test - Merck ${ }^{\mathrm{TM}}$ ) was used for COD determination on the effluent before cultivation and after cultivation and biomass elimination. 


\section{RESULTS AND DISCUSSION}

Lyophilized $R$. gelatinosus $\mathrm{R}_{1}$ biomass showed $7.1 \%$ moisture and chemical composition showed in Table 1. The high content of protein found to $R$. gelatinosus $\mathrm{R}_{1}$ biomass is a typical characteristic for photosynthetic bacteria biomass, signing for a possible use of the product in animal rations formulation.

Table 1 - Composition of $R$. gelatinosus $\mathrm{R}_{1}$ biomass

\begin{tabular}{lcc}
\hline \multirow{2}{*}{ Nutrient } & \multicolumn{2}{c}{$\%$} \\
\cline { 2 - 3 } & Dry weight & Wet weight \\
\hline Moisture & --- & 7.1 \\
Crude protein & 67.6 & 62.8 \\
Total carbohydrate & 27.6 & 25.6 \\
Lipid & 0.6 & 0.5 \\
Ash & 4.2 & 4.0 \\
\hline
\end{tabular}

Other authors have investigated the chemical composition of many photosynthetic bacteria biomass grown in different substrates. Balloni et al. (1986) used an association of photosynthetic bacteria ( $R$. gelatinosus among others) in pig farm waste to produce biomass with $7.5 \%$ moisture, $50.6 \%$ protein, $12 \%$ carbohydrates, $22.5 \%$ lipids and $15.5 \%$ ash (d.w.). In another experiment, Balloni et al. (1987) cultivated $R$. pseudomonas and $R$. fulvum in sugar refinery wastewater and found a biomass with $58 \%$ protein, $16.7 \%$ carbohydrates, $13.5 \%$ lipids and $12.8 \%$ ash (d.w.). Sasaki et al. (1981) cultivated two strains of $R$. gelatinosus in a miso-like effluent medium and found 62 and $63 \%$ protein in the bacteria biomass. Noparatnaraporn and Nagai (1986) cultivated $R$. sphaeroides $\mathrm{P} 47$ in dehydrated medium from pineapple peel waste and obtained a biomass with $66.6 \%$ protein. Kobayashi and Kurata (1978) cultivated Rhodopseudomonas capsulata in a synthetic medium and found the following composition (dry weight) for biomass: $60.9 \%$ crude protein, $9.9 \%$ lipids, $20.8 \%$ soluble carbohydrates, $2.9 \%$ crude fiber and $5.3 \%$ ash. These authors also tested the effect of mixing biomass into laying hens feed and found that the egg-laying rate tended to increase with the addition of photosynthetic bacterial cells. They also observed improvements in yolk color and carotenoid contents depending on the quantity of added bacterial cells, suggesting that the biomass carotenoids could be well absorbed and transferred into yolk.

Table 2 shows amino acid composition of $R$. gelatinosus $\mathrm{R}_{1}$ and other photosynthetic bacteria biomass. Lysine, methionine, glycine, histidine, isoleucine, leucine, phenylalanine, threonine, tryptophan and valine were present in good proportions in $R$. gelatinosus $\mathrm{R}_{1}$ biomass. According to Andriguetto et al. (1988), these are considered essential amino acids to lead to a maximum yield in poultry nutrition. $R$. gelatinosus $\mathrm{R}_{1}$ biomass amino acid composition was very similar to the findings of other authors for most amino acids, except to methionine and phenylalanine, which were in slightly lower concentrations (Kobayashi and Kurata; 1978; Sasaki et al., 1981; Noparatnaraporn and Nagai, 1986). The essential amino acids contents of $R$. gelatinosus $\mathrm{R}_{1}$ biomass may be considered similar to those of egg and soybean (Sasaki and Nagai, 1979), algae (Prasertsan et al., 1993 ${ }^{\mathrm{a}}$ ), yeast, animal and plant proteins (Noparatnaraporn and Nagai, 1986).

Some researchers have investigated photosynthetic bacteria biomass production in industrial effluents, such as sugar refinery wastewater (Balloni et al., 1987), miso factory wastewater (Sasaki et al., 1981) and pineapple peel waste (Noparatnaraporn and Nagai, 1986). While serving as a substrate, the pollutant load of the waste is reduced, as it happens in a sewage treatment. This may represent an advantageous practice to food industries because substrate cost is low, cost with installation of wastewater purifying equipment may be minimized, contamination control in process is easy, organisms utilized are not pathogenic and have high nutritional value (Kobayashi and Kurata, 1978). Prasertsan et al. $\left(1993^{\mathrm{a}, \mathrm{b}}\right)$ isolated and identified $R$. gelatinosus from seafood processing wastewater and cultivated the organism in the same substrate to investigate growth parameters and chemical oxygen demand (COD) removal. Authors found a biomass with 50\% protein and 86\% COD removal. Cultivation conditions described in this study led to an average $90 \%$ COD removal for poultry slaughterhouse wastewater. This process may be feasible and advantageous to the poultry industry once little expenses with wastewater treatment are required. Simple operations like filtration and decantation are enough to make effluent 
appropriate for $R$. gelatinosus $\mathrm{R}_{1}$ biomass production and sterility is not necessary because $R$. gelatinosus $\mathrm{R}_{1}$ predominates over other competing specia in this substrate.

Process productivity was around 0.072 g/l.day, since $250 \mathrm{~g}$ of biomass were produced from $500 \mathrm{l}$ of poultry slaughterhouse wastewater during seven days of cultivation. Productivity is typically lower for phototrophic bacteria biomass production than it is for heterotrophic organisms because cell densities achieved are low (Kobayashi and Kurata,
1978; Litchfiled, 1983). This is in agreement with other authors' works carried out with different photosynthetic bacteria (Sasaki and Nagai, 1979, Sasaki et al., 1981; Noparatnaraporn et al., 1983; Balloni et al., 1986; Noparatnaraporn and Nagai, 1986; Balloni et al., 1987; Prasertsan et al., $1993^{\mathrm{a}, \mathrm{b}}$ ). Cultivation of Rhodocyclus gelatinosus $\mathrm{R}_{1}$ in poultry slaughterhouse wastewater was feasible due to the simple incubation conditions

Table 2 - Amino acid composition of Rhodocyclus gelatinosus $\mathrm{R}_{1}$ biomass and other photosynthetic bacteria

\begin{tabular}{|c|c|c|c|c|c|}
\hline \multirow[b]{2}{*}{ Amino acid } & \multicolumn{5}{|c|}{$\%$ (dry weight) } \\
\hline & $\begin{array}{c}R . \\
\text { gelatinosus } \mathrm{R}_{1}\end{array}$ & $\begin{array}{c}R . \\
\text { capsulata } \\
\text { (Kobayashi and } \\
\text { Kurata, 1978) }\end{array}$ & $\begin{array}{c}R . \\
\text { gelatinosus } \\
\text { (Sasaki et al., 1981) }\end{array}$ & $\begin{array}{c}R . \\
\text { gelatinosus A1 } \\
\text { (Sasaki et al., 1981) }\end{array}$ & $\begin{array}{c}R . \\
\text { sphaeroides P47 } \\
\text { (Noparatnaraporn } \\
\text { and Nagai, 1986) }\end{array}$ \\
\hline aspartic acid & 5.74 & 4.56 & NA & NA & NA \\
\hline tyrosine & 2.90 & 1.71 & NA & NA & NA \\
\hline serine & 2.63 & 1.68 & NA & NA & NA \\
\hline glutamic acid & 6.85 & 5.34 & NA & NA & NA \\
\hline proline & 3.27 & 2.80 & NA & NA & NA \\
\hline glycine & 4.18 & 2.41 & NA & NA & NA \\
\hline alanine & 6.98 & 4.65 & NA & NA & NA \\
\hline tryptophan & 1.74 & 1.09 & NA & NA & NA \\
\hline cysteine & 0.59 & NA & NA & NA & NA \\
\hline valine & 4.56 & 3.51 & 3.42 & 3.75 & 2.68 \\
\hline methionine & 1.40 & 1.58 & 1.89 & 1.71 & 1.47 \\
\hline isoleucine & 3.18 & 2.64 & 2.73 & 2.96 & 1.78 \\
\hline leucine & 6.80 & 4.50 & 5.41 & 5.28 & 3.90 \\
\hline threonine & 3.52 & 2.70 & 1.99 & 1.93 & 2.87 \\
\hline phenylalanine & 3.03 & 2.60 & 3.10 & 3.05 & 2.36 \\
\hline lysine & 3.61 & 2.86 & 3.12 & 3.41 & 2.57 \\
\hline histidine & 1.83 & 1.25 & 1.13 & 1.01 & 0.96 \\
\hline
\end{tabular}

NA. not analyzed

required and profitable due to the valuable nutrient composition of the biomass produced. Moreover, the process led to a substantial COD removal in poultry slaughterhouse wastewater signing for an alternative waste treatment method. These characteristics make Rhodocyclus gelatinosus $\mathrm{R}_{1}$ an interesting microorganism for the production of biomass aiming at the supplementation of broiler and laying hen nutrition.

\section{RESUMO}

Rhodocyclus gelatinosus $\mathrm{R}_{1}$ foi cultivado fotoautotroficamente em águas residuais de abatedouro de aves dentro de colunas de vidro (90x670 mm) durante sete dias a $31 \pm 4^{\circ} \mathrm{C}$, sob anaerobiose e intensidade luminosa fornecida pela luz do dia e por três lâmpadas incandescentes (100W) mais quatro lâmpadas fluorescentes (40W). O cultivo obtido foi centrifugado $(4.500 \mathrm{xg} / 20 \mathrm{~min})$ e liofilizado, originando a biomassa bacteriana, que continha $7,1 \%$ de umidade. A determinação da composição centesimal indicou (base seca) 67,6\% de proteína bruta, $27,6 \%$ de carboidratos totais, $0,6 \%$ de 
lipídeos e 4,2\% de cinzas. A composição em aminoácidos da fração protéica da biomassa mostrou-se semelhante à relatada na literatura para Rhodocyclus gelatinosus e para outras bactérias fotossintetizantes. A redução na DQO do efluente após o cultivo e a retirada da biomassa foi da ordem de $90 \%$. A valiosa composição química da biomassa de Rhodocyclus gelatinosus $\mathrm{R}_{1}$ e o alto conteúdo em aminoácidos essenciais indicam o uso potencial desse produto na suplementação de ração para aves.

\section{ACKNOWLEDGMENTS}

E. H. G. P. thanks Miss Vanessa Panassi Gil for the COD analysis.

\section{REFERENCES}

Aiba. S.; Humprey, A. E. and Millis, N. F. (1971), Engenharia bioquímica. Campinas : ITAL.

Andriguetto, J. M.; Perly, L.; Minardi, I.; Flemming, J. S.; Gemael, A.; Souza, G. A. and Bona Filho, A. (1988), Nutrição animal 2. São Paulo : Nobel.

Balloni, W.; Carlozzi, P.; Ventura, S.; De Philippis, R. and Bosco, M. (1987), A three years experiment on the production of Rhodopseudomonas and Rhodospirillum biomass by outdoor culture on different wastes. $4^{\text {th }}$ Int. Conference on Biomass for Energy and Industry, 11-15 May, Orleans.

Balloni, W.; Carlozzi, P.; Ventura, S. and Sacchi, A. (1986), Microbial biomass for fertilizer use from the photo-anaerobic treatment of pig-wastes. Int. Symposium on Compost, 17-19 April, Udine.

Brasil, Ministério da Agricultura e Abastecimento (1998), Compêndio brasileiro de alimentação animal. Ministério da Agricultura e Abastecimento, Brasilia.

Brock, T. D.; Madigan, M. T.; Martinko, J. M. and Parker, J. (1994), Biology of microorganisms. Prentice Hall, New York.

Holt, J. G.; Bergey, D. H.; Krieg, N. R.; Sneath, P. H. A. and Williams, S. T. (1994), Anoxygenic phototrophic bacteria. In: Bergey's Manual of Determinative Bacteriology. Williams and Wilkins, Baltimore, pp. 353-376.

Kobayashi, M. and Kurata, S. (1978), The mass culture and cell utilization of photosynthetic bacteria. Process Biochem., 7, 27-30.

Litchfield, J. H. (1983), Single-cell proteins. Science, 219, 740-746.
Noparatnaraporn, N. and Nagai, S. (1986), Selection of Rhodobacter sphaeroides $\mathrm{P} 47$ as a useful source of single cell protein. J. Gen. Appl. Microbiol., 32, 351-359.

Noparatnaraporn, N.; Nishizawa, Y.; Hayashi, M. and Nagai, S. (1983), Single cell protein production from cassava starch by Rhodopseudomonas gelatinosa. J. Ferment. Technol., 61, 515-519.

Ponsano, E. H. G. (2000), Avaliação da capacidade pigmentante de biomassa de Rhodocyclus gelatinosus em frangos de corte. PhD Thesis, Chemistry Institute, UNESP, Araraquara, Brazil.

Pfennig, N. (1974), Rhodopseudomonas globiformis, sp. n., a new species of the Rhodospirillaceae. Arch. Microbiol., 100, 197-206.

Prasertsan, P.; Choorit, W. and Suwanno, S. (1993 a), Isolation, identification and growth conditions of photosynthetic bacteria found in seafood processing wastewater. World J. Microbiol. Biotechnol., 9, 590-592.

Prasertsan, P.; Choorit, W. and Suwanno, S. (1993 $\left.{ }^{\mathrm{b}}\right)$, Optimization for growth of Rhodocyclus gelatinosus in seafood processing effluents. World J. Microbiol. Biotechnol., 9, 593-596.

Sasaki, K. and Nagai, S. (1979), The optimum pH and temperature for the aerobic growth of Rhodopseudomonas gelatinosa, and vitamin $\mathrm{B}_{12}$ and ubiquinone formation on a starch medium. J. Ferment. Technol., 57, 383-386.

Sasaki, K.; Noparatnaraporn, N.; Hayashi, M.; Nishizawa, Y. and Nagai, S. (1981), Single cell protein production by treatment of soybean wastes with Rhodopseudomonas gelatinosa. J. Ferment. Technol., 59, 471-477.

Sasikala, C.; Ramana, C. V.; Chalam, A. V.; Jayasri, K. and Raghuveer Rao, P. (1995), A survey of purple non-sulfur anoxygenic phototrophic bacteria associated with some industrial effluents. Indian $J$. Exp. Biol., 33, 136-138.

Trüper, H. G. and Imhoff, J. F. (1992), The genera Rhodocyclus and Rubrivivax. In: Balows, A. et al. (ed.). The prokaryotes. Spring-Verlag, Berlin, 2, 2556-2561.

Received: February 15, 2001; Revised: September 19, 2001; Accepted: August 08, 2002. 